\title{
Nutritional Evaluation of Complementary Food Formulations from Maize, Soybean and Peanut Fortified with Moringa oleifera Leaf Powder
}

\author{
Dooshima Shiriki', Michael A. Igyor², Dick I. Gernah2* \\ ${ }^{1}$ Department of Biological Sciences, Benue State University, Makurdi, Nigeria \\ ${ }^{2}$ Department of Food Science and Technology, University of Agriculture, Makurdi, Nigeria \\ Email: 'gernah04@yahoo.com
}

Received 11 December 2014; accepted 2 April 2015; published 9 April 2015

Copyright (C) 2015 by authors and Scientific Research Publishing Inc.

This work is licensed under the Creative Commons Attribution International License (CC BY). http://creativecommons.org/licenses/by/4.0/

\begin{abstract}
Nutritional evaluation of complementary food formulations from maize, soybean and peanut fortified with Moringa oleifera leaf powder was carried out. Maize, soybean and peanut were blended in a ratio of 60:30:10 to produce a complementary food, which was then fortified. While the unfortified food product (sample $A$ ) served as control, the other three formulations were fortified with 5\%, 10\% and 15\% Moringa leaf powder to give three samples (B, C and D respectively) of fortified food. Nutritional composition determination and feeding trials were then carried out, using two weeks old male albino rats to determine the performance of the food formulations. While the crude protein, crude fibre, and ash contents of the diets increased significantly $(p<0.05)$ with fortification, with values ranging from $16.04 \%$ to $17.59 \%, 2.25 \%$ to $4.42 \%$ and $1.40 \%$ to $2.50 \%$ respectively, crude fat and carbohydrate decreased significantly $(p<0.05)$, with concomitant decrease in energy, with values ranging from $23.48 \%$ to $20.80 \%, 49.32 \%$ to $47.63 \%$ and $472.76 \%$ to $448.08 \mathrm{kcal} / 100 \mathrm{~g}$ respectively in samples $A$ to $D$. PER values significantly $(p<0.05)$ improved up to $10 \%$ substitution, from 1.77 in unfortified (sample $A$ ) to 1.90 in $10 \%$ fortified (sample $C$ ), but declined at $15 \%$ substitution (sample D) to 1.69. Similarly, NPR values increased from 0.71 to 0.76 and 0.68. However, all the PER values including that of Nestle Cerelac (2.04) were lower than, though within the same range, with the value of 2.10 recommended by the Protein Advisory Group (PAG) for complementary foods. Sample C (10\% Moringa flour blend) gave the best performance after rat feeding trials.
\end{abstract}

\section{Keywords}

Fortification, Complementary Food, Nutritional Evaluation, Substitution, Moringa Leaf Powder,

\footnotetext{
${ }^{*}$ Corresponding author.
}

How to cite this paper: Shiriki, D., Igyor, M.A. and Gernah, D.I. (2015) Nutritional Evaluation of Complementary Food Formulations from Maize, Soybean and Peanut Fortified with Moringa oleifera Leaf Powder. Food and Nutrition Sciences, 6, 494-500. http://dx.doi.org/10.4236/fns.2015.65051 


\section{Food Formulations}

\section{Introduction}

Traditional complementary foods in the developing countries are known to be of low nutritive value and are characterized by low protein, low energy density and high bulk, because they are usually cereal-based. The protein content of cereals such as maize and guinea corn, which is often used, is of poor quality, being low in lysine and tryptophan amino acids which are indispensable for the growth of the young child. For example maize pap or koko has been implicated in the aetiology of protein-energy malnutrition in children during the complementary period [1]. This nutritional deficiency can be corrected by several ways, one of which is supplementation with grain legumes or oil seeds and fortification with Moringa olifera leaf powder [1] [2]. Legumes, though very nutritionally complementary, are rarely used for complementary and are introduced much later (after six months of age) because of the problems of indigestibility, flatulence, and diarrhea associated with their use [3].

The maize grain contains high carbohydrate which in turn provides the energy and calorie requirement of people consuming it. Also the lipid content found in the germ is a good source of energy and fatty acids. In Nigeria maize food dishes are numerous. These include pap, tuwo, masa, waina, ibier, choko, mumu, couscous, gwate and pop corn. Apart from food, maize is also used for medicine and as a raw material for the industries [4].

Soybean is an important source of high quality, inexpensive protein and oil. At 38\% soybean has the highest protein content of all food crops and is second only to peanut in terms of oil content (18\%) among food legumes. Compared to other protein-rich foods such as meat, fish, and eggs, soybeans is by far the cheapest. It also has a superior amino-acid profile compared to other sources of plant protein. The crops main use is flour, protein products and animal feed [5] [6].

Groundnut contains high quality edible oil, easily digestible protein and carbohydrates. A nutritious peanut butter is prepared from groundnut. It is also a significant source of resveratrol, a chemical compound that is reported to have a number of beneficial health effects, such as anti-cancer, antiviral, neuro protective, anti-aging, anti-inflammatory and life prolonging effects [6].

Moringa oliefera is a "miracle plant" that has almost all the minerals and vitamins that the body needs for vibrant and good health. The leaves, pods and flowers of this plant which are used as vegetable in many parts of the world have great nutritional value [7]. Almost all parts of the plant have therapeutic value. The leaves are especially beneficial in the treatment of many ailments due to their various medicinal properties and their rich iron content. Moringa leaves and pods can be an extremely valuable source of nutrients for people of all ages. The leaves can be dried, made into powder [2] and stored for use when needed.

Strategic use of such inexpensive high protein sources that complement the amino acid pattern of cereal staple foods is highly recommended to upgrade the nutritional status and prevent protein-energy malnutrition in the developing world. The fortification of maize, soybean and peanut food formulations with Moringa oleifera leaf powder can dramatically improve their protein quality and micronutrient content, with little or no increase in the production cost [8].

The aim of this study was therefore to assess the nutritional value of Moringa oleifera leaf powder supplemented maize-soybean-peanut complementary food formulations.

\section{Materials and Methods}

\subsection{Source of Materials}

About $6.0 \mathrm{~kg}$ of yellow maize (Zea mays, TZSR-Y); $4.0 \mathrm{~kg}$ of soybeans (Glycine max, TGX 536-OZD) and 2.0 kg peanuts (Arachis hypogea, QPG); 2009 harvest year seeds were purchased from Benue State Agricultural and Rural Development Authority (BNARDA), Makurdi; while $4.0 \mathrm{~kg}$ of fresh Moringa oliefera leaves was obtained from a plant opposite Special Science Secondary School, University of Agriculture Road, Makurdi. Nestle Cerelac (a maize and milk infant food made by nestle foods Nigeria PLC, Lagos), corn starch and corn oil were purchased from a local supermarket in Makurdi, while rice husk was obtained from a local mill in Makurdi. Casein standard was obtained from the Department of Zoology University of Jos, Nigeria. Albino rats (21 in 
number, 3 weeks old males) were purchased from the College of Health Sciences Animal House, Benue State University, Makurdi.

\subsection{Material Preparation}

Maize, Soybeans and Peanut flours were prepared using the method described by Solomon [1]. The clean yellow maize, soybeans and peanut were separately washed in clean tap water. The maize and peanut were air dried for 12 hours. The soybeans were soaked in tap water for 12 hours and washed by rubbing between the palms to remove testa, then washed again several times with more water until most of the testa were washed out. It was then boiled for 15 minutes in water, air dried for 48 hours and then dried in an oven at $70^{\circ} \mathrm{C}$ for 30 minutes. (Soaking and roasting were intended to remove the beany flavour). The peanut was also roasted in an oven at $70^{\circ} \mathrm{C}$ for 30 minutes and the seed coat removed to get clean partially roasted peanuts. The maize and the processed soybeans were separately milled in a disc attrition mill (ASIKO All, Addis, Nigeria) and sieved using a $500 \mu \mathrm{m}$ sieve. Peanut flour was obtained by pounding the roasted peanut in a wooden mortar for size reduction and milling in a 2L mistral grinder (model SAISHO, S-T4PN) into a smooth powder.

Moringa oleifera leaf powder was prepared using a modification of the method described by Gernah and Sengev [9]. Moringa leaves were washed in clean tap water containing 5\% Sodium chloride. They were then dried indoors at room temperature for four (4) days, grounded into powder and sieved with a fine sieve (500 $\mu \mathrm{m})$. The powder was then dried to constant weight in a hot air oven at $60^{\circ} \mathrm{C}$. All flours were packaged in black polyethylene bags and stored in air tight plastic containers away from light.

\subsection{Food Product and Diet Formulation}

Maize, soybeans and peanut flours were blended in a ratio of 60:30:10. This ratio was arrived at, based on their protein content through material balancing [10] to give $16 \mathrm{~g}$ protein/100g food as recommended by the protein advisory group [11] for infant diets, as described by Solomon [1]. The blends were mixed thoroughly using a Phillips blender (model HR-1702) and then divided into four parts of $2.5 \mathrm{~kg}$ each. While one part was used unfortified as control food sample (A), the remaining three parts were fortified with 5\% (125 g), $10 \%$ (250 g) and 15\% (375 g) Moringa oleifera powder, giving samples B, C and D respectively. The basal diet consisted of corn starch: 80 g/100g, corn oil: 10 g/100g, common table salt: 4 g/100g, sugar: 1 g/100g, vitamin premix: 1 g/100g and non-nutritive fibre (rice husk): $4 \mathrm{~g} / 100 \mathrm{~g}$. The diets were packaged in low density dark-coloured polyethylene bags and stored in $500 \mathrm{ml}$ plastic containers with air tight lids at room temperature from where samples were taken with Casein (milk protein) and Nestle Cerelac as standards.

\subsection{Nutritional Studies}

Feeding trials were carried out with male Wister albino rats using the method describe by Gernah et al. [12]. The 21 rats were randomly distributed to seven cages based on weight equivalent with 3 rats in a cage. The cages were secured with wire mesh to prevent the rats from escaping and placed on cardboard paper for the collection of faeces as well as to account for feed spillages. Each animal group (in individual cages) was fed one of the test diets, control or the basal diet. The rats were given $10 \mathrm{~g}$ of food per day (which was increased to $30 \mathrm{~g}$ by day 14 ) and water ad-libitum for 28 days.

\subsection{Analyses}

\subsubsection{Proximate Composition}

Proximate composition of the different ingredients as well as the food formulations was carried out using the method of [13].

\subsubsection{Nutritional Studies}

Protein quality parameters used as indices for the performance of the diets during feeding trials were determined using standard methods. The total food intake of the rats was determined by recording the food left after daily intake. Mean daily feed intake was then calculated according to [13]:

$$
\text { MDFI }=\frac{\text { Total quantity consumed }}{\text { No. of days of feeding }}
$$


Daily weight gain was obtained by weighing all the rats individually on a sensitive top loading weighing balance (Metra, model TL 600). Mean daily weight gain was then calculated according to [13]:

$$
\text { MDWG }=\frac{\text { Total weight gain }}{\text { No. of days of feeding }}
$$

Using the mean daily weight gain values obtained, the protein efficiency ratio (PER), relative protein efficiency ratio (R-NPR) and Net protein retention (NPR), relative net protein ratio (R-NPR) and feed conversion efficiency (FCE) were estimated by the method of Pellet and Young [14].

$$
\begin{gathered}
\text { PER }=\frac{\text { Weight gain }}{\text { Total protein intake }} \\
\text { R-PER }=\frac{\text { PER of diet } \times \text { ANCR Casein }(2.5)}{\text { PER of Casein diet }}
\end{gathered}
$$

*ANCR-Animal Nutrition Research Council.

$$
\begin{gathered}
\mathrm{NPR}=\frac{\text { Weight gain }+ \text { Loss by } 0 \% \text { Protein group }}{\text { Weight of protein consumed }} \\
\mathrm{R}-\mathrm{NPR}=\frac{\text { NPR of diet } \times \text { ANCR Casein }(4.02)}{\text { NPR of Casein diet }} \\
F C E=\frac{\text { Daily feed intake }}{\text { Daily weight gain }}
\end{gathered}
$$

All faeces collected was stored in the refrigerator until the end of the feed time when they were put together (per individual cages) and dried, weighed, milled into powder using a disc attrition mill (ASIKO All, Addis, Nigeria) and their nitrogen content determined by the method of [13]. Apparent digestibility (AD) was estimated using the method described by Hsu et al. [15].

$$
\mathrm{AD}(\%)=\frac{\text { Nitrogen in feed }- \text { Nitrogen in faeces }}{\text { Nitrogen in feed }} \times \frac{100}{1}
$$

\subsubsection{Statistical Analysis}

The data generated were subjected to analysis of variance (ANOVA) as described by Steel and Torrie (1990). Separation of means was done by Tukey's Test (Ihekoronye and Ngoddy, 1985), to determine whether significant differences existed.

\section{Results and Discussion}

\subsection{Proximate Composition}

Table 1 shows the proximate composition of the various ingredients used for the complementary food formulations used in this study. While Moringa oleifera leaf powder has the highest crude protein, crude fibre and ash contents of $26.40 \%, 16.80 \%$ and $8.50 \%$ respectively, peanut had the highest crude fat content of $50.90 \%$, maize had the highest carbohydrate content of $68.00 \%$ and soybeans had the highest energy value of $639.70 \mathrm{kcal} / 100 \mathrm{~g}$. Gernah and Sengev [9] also reported high values of $27.82 \mathrm{~g} / 100 \mathrm{~g}$ protein, $19.32 \mathrm{~g} / 100 \mathrm{~g}$ crude fibre, but low values of $2.10 \mathrm{~g} / 100 \mathrm{~g}$ for crude fat and $38.20 \mathrm{~g} / 100 \mathrm{~g}$ for carbohydrates in the leaf powder. A blend of these ingredients was therefore expected to give complementary foods of very balanced nutritional value, in terms of macro-and micro-nutrients.

The proximate composition of the food formulations is presented in Table 2. While the crude protein, crude fibre, and ash contents of the diets increased significantly $(\mathrm{p}<0.05)$ with fortification, with values ranging from $16.04 \%$ to $17.59 \%, 2.25 \%$ to $4.42 \%$ and $1.40 \%$ to $2.50 \%$ respectively, crude fat and carbohydrate decreased significantly ( $\mathrm{p}<0.05$ ), with concomitant decrease in energy, with values ranging from $23.48 \%$ to $20.80 \%, 49.32 \%$ to $47.63 \%$ and 472.76 to $448.08 \mathrm{kcal} / 100 \mathrm{~g}$ respectively. This could be due to substitution effect as evidenced by the nutritional composition of the individual ingredients. 
Table 1. Proximate composition of ingredients for maize/soybean/peanut food formulations and Moringa oleifera leaf powder (\%).

\begin{tabular}{|c|c|c|c|c|c|}
\hline Parameter & Maize & Soybean & Peanut & MLP & LSD \\
\hline Moisture & $12.20^{\mathrm{a}} \pm 0.02$ & $1.00^{\mathrm{d}} \pm 0.01$ & $1.80^{c} \pm 0.01$ & $6.50^{\mathrm{b}} \pm 0.02$ & 0.10 \\
\hline Crude Protein & $10.40^{\mathrm{d}} \pm 0.03$ & $25.00^{\mathrm{b}} \pm 0.10$ & $23.00^{c} \pm 0.10$ & $26.40^{\mathrm{a}} \pm 0.03$ & 0.13 \\
\hline Crude Fat & $5.40^{c} \pm 0.01$ & $50.50^{\mathrm{b}} \pm 0.02$ & $50.90^{\mathrm{a}} \pm 0.01$ & $3.30^{d} \pm 0.01$ & 0.30 \\
\hline Crude Fibre & $2.40^{\mathrm{b}} \pm 0.01$ & $1.10^{\mathrm{d}} \pm 0.05$ & $2.10^{c} \pm 0.05$ & $16.80^{\mathrm{a}} \pm 0.10$ & 0.10 \\
\hline Ash & $1.60^{\mathrm{b}} \pm 0.03$ & $1.10^{\mathrm{c}} \pm 0.10$ & $1.00 \mathrm{~d} \pm 0.02$ & $8.50^{\mathrm{a}} \pm 0.02$ & 0.10 \\
\hline Carbohydrate & $68.00^{\mathrm{a}} \pm 0.10$ & $21.30^{\mathrm{c}} \pm 0.01$ & $21.20^{\mathrm{d}} \pm 0.01$ & $38.50 \mathrm{~b} \pm 0.01$ & 0.10 \\
\hline Energy (Kcal/100g) & $362.20^{c} \pm 0.02$ & $639.70^{\mathrm{a}} \pm 0.01$ & $634.90^{\mathrm{b}} \pm 0.02$ & $307.30^{\mathrm{d}} \pm 0.02$ & 0.03 \\
\hline
\end{tabular}

Values are means \pm standard deviations of triplicate determinations. Means with the same superscript within the row are not significantly different (p > 0.05). Key: LSD = Least Significant Difference; MLP = Moringa oleifera Leaf Powder

Table 2. Proximate composition of maize/soybean/peanut food formulations fortified with Moringa oleifera leaf powder (\%) compared to nestle Cerelac and Rrecommended Dietary Allowances (RDAs).

\begin{tabular}{|c|c|c|c|c|c|c|c|}
\hline Parameters & A & B & $\mathrm{C}$ & $\mathrm{D}$ & $\begin{array}{l}\text { Nestle } \\
\text { Cerelac }\end{array}$ & $\begin{array}{c}\text { RDA } \\
(<3 \text { yrs })\end{array}$ & LSD \\
\hline Moisture & $7.51^{\mathrm{a}} \pm 0.02$ & $7.36^{\mathrm{b}} \pm 0.01$ & $7.20^{\mathrm{c}} \pm 0.01$ & $7.06^{\mathrm{d}} \pm 0.01$ & $2.50^{\mathrm{e}} \pm 0.00$ & & 0.02 \\
\hline Crude Protein & $16.04^{\mathrm{d}} \pm 0.02$ & $16.56^{\mathrm{c}} \pm 0.04$ & $17.08^{\mathrm{b}} \pm 0.01$ & $17.59^{\mathrm{b}} \pm 0.01$ & $15.00^{\mathrm{e}} \pm 0.00$ & 16 & 0.04 \\
\hline Crude Fat & $23.48^{\mathrm{a}} \pm 0.01$ & $22.58^{\mathrm{b}} \pm 0.01$ & $21.60^{\mathrm{c}} \pm 0.03$ & $20.80^{d} \pm 0.01$ & $9.00^{\mathrm{e}} \pm 0.00$ & 25 & 0.03 \\
\hline Crude Fibre & $2.25^{\mathrm{d}} \pm 0.02$ & $2.94^{\mathrm{c}} \pm 0.02$ & $3.68^{\mathrm{b}} \pm 0.01$ & $4.42^{\mathrm{a}} \pm 0.02$ & $2.00^{\mathrm{e}} \pm 0.00$ & - & 0.03 \\
\hline Ash & $1.40^{\mathrm{e}} \pm 0.01$ & $1.70^{\mathrm{d}} \pm 0.02$ & $2.20^{\mathrm{c}} \pm 0.01$ & $2.50^{\mathrm{b}} \pm 0.01$ & $3.30^{\mathrm{a}} \pm 0.02$ & - & 0.02 \\
\hline Carbohydrate & $49.32^{\mathrm{b}} \pm 0.02$ & $48.86^{\mathrm{c}} \pm 0.01$ & $48.24^{d} \pm 0.01$ & $47.63^{e} \pm 0.03$ & $68.20^{\mathrm{a}} \pm 0.00$ & 95 & 0.03 \\
\hline Energy (kcal/100g) & $472.76^{\mathrm{a}} \pm 0.03$ & $464.60^{\mathrm{b}} \pm 0.02$ & $455.68^{\mathrm{c}} \pm 0.0$ & $448.08^{\mathrm{d}} \pm 0.01$ & $413.80^{\mathrm{e}} \pm 0.00$ & 740 & 0.03 \\
\hline
\end{tabular}

Values are means \pm standard deviations of triplicate determinations. Means with the same superscripts within the row are not significantly different ( $p$ > 0.05). Key: A = Maize, soybean and peanut diet; $B=$ Maize, soybean, peanut $+5 \%$ Moringa diet; $C=$ Maize, soybean, peanut $+10 \%$ Moringa diet; $\mathrm{D}=$ Maize, soybean, peanut + 15\% Moringa diet; RDA = Recommended Dietary Allowance (Gordon, 1999); LSD = Least Significant Difference.

Proteins are essential constituents of all body tissues, which help the body to produce new tissues. They are therefore extremely important during growth, pregnancy and when recovering from wounds. It is therefore recommended that, infants should consume about $16 \mathrm{~g}$ of protein daily [16]. A $100 \mathrm{~g}$ meal of the fortified complementary foods will therefore satisfy over $100 \%$ of their protein needs.

Though crude fibre does not contribute nutrients to the body, it adds bulk to food thus facilitating bowel movements (peristalsis) and preventing many gastrointestinal diseases in man [17]. The increase in ash content from $1.40 \%$ to $2.50 \%$ is an indication of increase in mineral content of the food formulations. Minerals are vital to the functioning of many body processes. They are critical players in nervous system functioning, other cellular processes, water balance, and structural (e.g. skeletal) systems. These increases in protein, fibre and ash (minerals) therefore, agree with the suggestions by Ossai and Malomo [18] and Solomon [1] that protein and micronutrient malnutrition in Nigeria could be solved with locally available raw materials at a much cheaper cost.

The decrease in carbohydrate with fortification is expected and could also be due to substitution effect, as a result of the low carbohydrate content (38.50\%) of Moringa leaf powder. Gernah and Sengev [9] also reported a low carbohydrate content of $38.20 \mathrm{~g} / 100 \mathrm{~g}$ in leaf flour in Moringa leaf powder. Carbohydrates provide heat and energy for all forms of body activity. Deficiency can cause the body to divert proteins and body fat to produce needed energy, thus leading to depletion of body tissues [17]. However, at the recommended daily allowance (RDA) of $3000 \mathrm{kcal}$ for infants [19], the fortified food formulations are a very good source of energy with values ranging from 472.76 to $448.08 \mathrm{kcal} / 100 \mathrm{~g}$. The decrease in fat content could be advantageous to health as well as in extending product shelf life as reported by [6].

\subsection{Protein Quality}

Table 3 presents the protein quality indices of the food formulations. 
Table 3. Protein quality values of maize/soybean/groundnut food formulations fortified with Moringa oleifera leaf powder compared to nestle Cerelac.

\begin{tabular}{ccccccc}
\hline Parameter & A & B & C & D & NC & LSD \\
\hline PER & $1.77^{\mathrm{c}} \pm 0.02$ & $1.89^{\mathrm{b}} \pm 0.01$ & $1.90^{\mathrm{b}} \pm 0.02$ & $1.69^{\mathrm{d}} \pm 0.01$ & $2.04^{\mathrm{a}} \pm 0.01$ & 0.02 \\
R-PER & $0.71^{\mathrm{c}} \pm 0.02$ & $0.76^{\mathrm{b}} \pm 0.01$ & $0.76^{\mathrm{b}} \pm 0.01$ & $0.68^{\mathrm{c}} \pm 0.01$ & $0.82^{\mathrm{a}} \pm 0.02$ & 0.02 \\
NPR & $1.89^{\mathrm{e}} \pm 0.01$ & $2.15^{\mathrm{c}} \pm 0.02$ & $2.38^{\mathrm{b}} \pm 0.01$ & $2.00^{\mathrm{d}} \pm 0.10$ & $2.78^{\mathrm{a}} \pm 0.01$ & 0.08 \\
R-NPR & $0.47^{\mathrm{d}} \pm 0.01$ & $0.54^{\mathrm{b}} \pm 0.03$ & $0.59^{\mathrm{b}} \pm 0.02$ & $0.50^{\mathrm{c}} \pm 0.02$ & $0.69^{\mathrm{a}} \pm 0.01$ & 0.04 \\
FCE & $3.10^{\mathrm{d}} \pm 0.03$ & $3.31^{\mathrm{b}} \pm 0.02$ & $3.38^{\mathrm{a}} \pm 0.02$ & $3.25^{\mathrm{c}} \pm 0.02$ & $3.39^{\mathrm{a}} \pm 0.01$ & 0.20 \\
AD & $1.52^{\mathrm{e}} \pm 0.02$ & $1.95^{\mathrm{c}} \pm 0.01$ & $2.03^{\mathrm{b}} \pm 0.02$ & $1.90^{\mathrm{d}} \pm 0.02$ & $2.21^{\mathrm{a}} \pm 0.01$ & 0.04 \\
\hline
\end{tabular}

Values are means \pm standard deviations of triplicate determinations. Values with the same superscript within the row are not significantly different (p $>$ 0.05). KEY: A = Maize, soybean and peanut diet, B = Maize, soybean and peanut $+5 \%$ Moringa diet, $C=$ Maize, soybean and peanut $+10 \%$ Moringa diet, $\mathrm{D}=$ Maize, soybean and peanut $+15 \%$ Moringa diet, NC $=$ Nestle Cerelac, PER = Protein Efficiency Ratio, R-PER $=$ Relative Protein Efficiency Ratio, NPR = Net Protein Ratio, R-NPR = Relative Net Protein Ratio, FCE = Feed Conversion Efficiency, AD = Apparent Digestibility, LSD = Least Significant Difference.

Moringa oleifera leaf powder fortification significantly $(\mathrm{p}<0.05)$ improved PER of the complementary foods up to $10 \%$ substitution, from 1.77 to 1.90 , but declined at $15 \%$ substitution to 1.69 and NPR from 0.71 to 0.76 and 0.68 . This could be because of the increase in protein and micronutrient content of the food formulations, which were utilized by the experimental animals. However all the PER values, including that of Nestle Cerelac (2.04) were lower than, though within the same range with the value of 2.10 recommended by the Protein Advisory Group [11] for complementary foods. Both PER and NPR are indices of protein quality. Protein Efficiency Ratio (PER) indicates the relationship between weight gain in the test animals and the corresponding protein intake, while NPR relates the weight changes in the animals fed the test diets to those fed the control diet. Feed conversion efficiency (FCE) and apparent digestibility (AD) also followed a similar trend with increase in Moringa leaf powder substitution. While feed conversion efficiency measures how well an animal actually uses the feed, and it is expressed as body mass produced per kg dry matter intake, apparent digestibility is the percentage of feed retained by an animal.

The higher PER, NPR, FCE and AD values of fortified food products could be due to utilization of the increased protein and micronutrients from the Moringa oleifera leaf powder by the experimental animals. These observations are consistent with earlier reports of significant increases in PER in rats as a result of improved nutritional composition [20]. The lower values of protein indices recorded for the 15\% Moringa leaf powder fortified food product (sample D) could be because the lower quantity consumed by the experimental rats. This could be due to the characteristic bitter taste imparted by the higher quantity of Moringa leaf powder [7]. A similar trend was observed by Sengev et al. [21] with Moringa oleifera leaf powder substituted wheat bread. Fuglie [7] reported that, though there is no known side effect as to over consumption of Moringa, it has a characteristics bitter taste when consumed directly or added in higher concentration to food. Meanwhile, it has been established that rats prefer a diet with some sweet taste and may consume higher quantities of such diets [22].

\section{Conclusion}

This study has shown that Moringa oleifera leaf powder fortification can be employed to produce acceptable and improved protein quality food products from maize/soybean and peanut, which can be used as complementary foods. Fortification increases nutrient quantity, quality and availability as shown by the improvement in protein quality indices during rat feeding studies. Sample C (10\% Moringa flour blend) gives the best performance after rat feeding trials.

\section{Acknowledgements}

We wish to acknowledge the staff of the Nutrition Laboratory of the Department of Food Science and Technology, University of Agriculture, Makurdi, for their assistance in the rat feeding trials. 


\section{References}

[1] Solomon, M. (2005) Nutritive Value of Three Potential Complementary Foods Based on Cereals and Legumes. The African Journal of Food, Agriculture, Nutrition and Development (AJFAND), 5, 1-14.

[2] Olushola, A.T.E. (2006) Achieve Vibrant Health with Nature. University of Jos Consultancy Ltd. Press, Jos, 120-113.

[3] Onofiok, N. and Nnanyelugo, D.O. (1992) Nutrient Intake of Infants of High and Low Socio-Economic Groups in Nsukka, Nigeria. Occasional Paper, Department of Home Science and Nutrition, University of Nigeria, Nsukka.

[4] Abdulrahaman, A.A. (1997) Medical Importance of Plants. In: The Frontiers, 1st Edition, Elepo Press, Ilorin, $22-25$.

[5] WHO (1998) Complementary Feeding of Young Children in Developing Countries: A Review of Current Scientific Knowledge. WHO/NUT/98, Geneva.

[6] Saskia, D.P. and Martin, W.B. (2008) Current and Potential Role of Specially for Mulated Foods and Food Supplements for Preventing Malnutrition among 6 - 23 Months Old and Treating Moderate Malnutrition among 6 - 59 Months Old Children. WHO, UNI-CEF, WFP and UNHCR Consultation on the Dietary Management of Moderate Malnutrition in Under-5 Children by the Health Sector, Rome.

[7] Fuglie, L.J. (2001) Combating Malnutrition with Moringa. Church World Service, Senegal.

[8] El-Adawy, T.A. (1997) Effect of Sesame Protein Supplementation on Nutritional, Physical, Chemical and Sensory Properties of Wheat Flour Bread. Food Chemistry, 59, 7-14. http://dx.doi.org/10.1016/0308-8146(95)00197-2

[9] Gernah, D.I. and Sengev, A.I. (2011) Effect of Processing on Some Chemical Properties of the Leaves of the Drumstick Tree (Moringa oleifera). Nigerian Food Journal, 29, 70-77.

[10] Smith, P.G. (2003) Introduction to Food Process Engineering. Kluwer Academic/Plenum Publishers, New York. http://dx.doi.org/10.1007/978-1-4615-0201-2

[11] PAG (1971) Guidelines on Protein Rich Mixtures for Use in Weaning Foods. Protein Advisory Group, United Nations, 45-76.

[12] Gernah, D.I., Ariahu, C.C. and Ingbian, E.K. (2012) Nutritional and Sensory Evaluation of Food Formulations from Malted and fermented Maize (Zea mays L.) Fortified with Defatted Sesame (Sesamun indicum L.) Flour. African Journal of Food Agriculture, Nutrition and Development, 12, 6614-6631.

[13] AOAC (2012) Official Methods of Analysis. 18th Edition, Association of Official Analytical Chemists, Arlington, 806-842.

[14] Pellet, P.I. and Young, V.R. (1980) Nutritional Evaluation of Protein Foods. The United Nation's University Hunger Programme. Food and Nutrition Bulletin, Suppl. 4, The United University, Tokyo.

[15] Hsu, H.W., Vavak, D.I., Satterlee, L.D. and Miller, G.A. (1977) A Multienzyme Technique for Estimating Protein Digestibility. Journal of Food Science, 42, 1269-1273. http://dx.doi.org/10.1111/j.1365-2621.1977.tb14476.x

[16] Muller, H.G. (1988) An Introduction to Tropical Food Science. Cambridge University Press, Cambridge, 59-64.

[17] Gordon, M.W. (1999) Perspectives in Nutrition. 4th Edition, McGraw Hill, New York, 75-372.

[18] Ossai, G.E.A. and Malomo, O. (1988) Nutritional and Sensory Evaluation of a New Cereal-Legume Wearing Food. Nigerian Food Journal, 6, 23-33.

[19] Gaman, P.M. and Sherrington, K.B. (1990) The Science of Food. An Introduction to Food Science, Nutrition and Microbiology. 3rd Edition, Pergamon Press, Oxford and New York, 104-115.

[20] Oluwamukomi, M.O., Eleyemi, A.F., Enujiugha, V.N. and Atofarati, S.O. (2003) Nutritional, Physico-Chemical and Sensory Evaluation of Sorghum and Cowpea based Complementary Formulations. Nigerian Food Journal, 21, 11-17.

[21] Sengev, A.I., Abu, J.O. and Gernah, D.I. (2013) Effect of Moringa oleifera Leaf Powder Supplementation on Some Quality Characteristics of Wheat Bread. Food and Nutrition Sciences, 4, 270-275. http://dx.doi.org/10.4236/fns.2013.43036

[22] Steinke, F.H. (1977) Protein Efficiency Ratio Pitfalls and Causes of Variability: A Review. Cereal Chemistry, 54, 949957. 